\title{
Vertical electrical sounding of soils and permafrost of marine terraces of Gronfjord (Svalbard archipelago)
}

\author{
Ivan Alekseev*, Evgeny Abakumov
}

Saint Petersburg State University, Department of Applied Ecology, Saint Petersburg, Russia

\begin{abstract}
Vertical electrical resistivity sounding (VERS) of soil-permafrost strata has been performed during the field work within the sea terraces of Gronfjord (Svalbard archipelago, West Spitsbergen island). Vertical electrical resistivity sounding of soilpermafrost strata was performed by portable device LandMapper. Then these data have been analyzed via ZondIP software (1d model). Apparent electrical resistivity values on the soil-permafrost strata usually change rapidly. It was established that studied soils with different origin and morphological properties are referred to 2 trunks, 2 orders, 4 types and 7 subtypes. Histic Gleysols, Cryosols, Gleysols and their subtypes have been investigated within the key plots (Grendasselva, Aldegonda rivers and catena on the sea terrace in surroundings of Barentsburg aerodrome). Several trends in profile distribution of electrical resistivity values have been distinguished. The main is connected with monotonous increasing of electrical resistivity values with a depth. Values of apparent electrical resistivity increase rapidly on the border of active layer-permafrost layer. The contrasts in profile distribution of electrical resistivity values are caused mainly by differences in water content, texture class and degree of strata heterogeneity (due to cryogenic processes). The depths of active layer-permafrost boundary have been distinguished using ZondIP software. Regional differences in this indicator may be explained not only by local differences in thermal regime of soil and permafrost layers, but also by different character of anthropogenic influence on key plots. Vertical electrical resistivity sounding method provides significant information for understanding soil electrical properties without any mechanical disturbances of soil cover. The data obtained is clearly coincided with field work data on soil morphology.
\end{abstract}

Key words: VERS, cryogenic soils, active layer, permafrost, Gronfjord

DOI: $10.5817 / \mathrm{CPR} 2016-2-19$

Received November 8, 2016, accepted January 30, 2017.

*Corresponding author: Ivan Alekseev <alekseevivan95@gmail.com>

Acknowledgements: This study was conducted in cooperation with Arctic and Antarctic Research Institute (Saint Petersburg, Russia) and supported by Russian Foundation for basic research, grant 16-34-60010, Russian presidents’ grant for Young Doctors of Science № MD-3615.2015.4. 


\section{Introduction}

Polar ecosystems are crucial in sense of polar biomes functioning. Soils are the part of polar ecosystems and play a key role in accumulation, transformation, redistribution and migration of various chemical compounds and elements (Tomashunas et Abakumov 2014). As a whole, soils are as a linkage between small and large geological cycle of matter and energy fluxes (Tarnocai et al. 2009, Zubrzycki et al. 2014). There are a lot of key issues in the study of soils in polar region: soil diversity, soil evolution, soil geography and interpretation of soil properties via the prism of bioclimatogenic or geogenic approaches (Goryachkin 2010). Existing frictions in interpretation of polar soils taxonomy, classification and morphology lead to necessity of development of three-dimensional approaches for studying soils, i.e. the study of soil cover, soil cover pattern, genesis, evolution and ecology. Application of such methods to the polar regions seems to be a significant goal of modern pedology (Goryachkin 2010).

Besides, studying of polar soils has a practical value due to intensive development of Arctic region infrastructure on the one hand and high vulnerability of polar ecosystems on the other. It has a particular scientific interest to study the soil cover of particular areas of polar regions, where anthropogenic factor strongly affects the soil-forming process. From this reason soil investigation in the area of West Spitsbergen where coal exploration is quite developed seem to be very prominent. Soilforming, taxonomy (Forman et Miller 1984, Mann et. al. 1986, Pereverzev et Litvinova 2010) functioning (Dobrovolsky 1990) and chemical pollution (Plichta et Kuczynska
1991) of soils of Svalbard archipelago have been studied during the last decades.

Permafrost layer stratification of Arctic and Antarctic has been investigated by few geophysical approaches (Scott et al. 1990, Abakumov et Parnikoza 2015, Abakumov et Tomashunas 2016, Hoekstra et McNeill 1973, Hoekstra et al. 1975, Scott et Kay 1988, Olhoeft 1978). In these works it has been shown that vertical electrical resistivity sounding allows to determine the active layer thickness without mechanical disturbances of soil-permafrost layer (Abakumov et Parnikoza 2015). Initiation of studying of soil electrical parameters is connected mainly with Pozdnyakov (Pozdnyakov et al. 2006, Pozdnyakov 2008). The author showed that the manifestations of soil electrical parameters are described by electrophysical laws of Maxwell, Poisson, Laplace, and Boltzmann. According to the author works these laws could serve as prerequisites for formation of the basis for the theoretical interpretation of the behavior of electrical parameters in the soils.

The aim of this study is connected with determining of the active layer thickness and its spatial dynamics in different landscapes of sea terraces of Gronfjord by electrical resistivity method.

The objectives of our investigation: (1) To apply the VERS methodology (Schlumberger approach) for evaluation the active layer thickness depths in selected Gleyic and Cryogenic soils of studied area; (2) To specify the structure of the soil profiles; (3) To establish characteristic trends of vertical profile of electrical resistivity values (Ra) and to determine the differences in them. 


\section{Material and Methods}

\section{Regional setting}

The investigation has been carried out in areas of arctic tundra environments located on marine terraces along the coasts of Gronfjord ( $\left.78^{\circ} 03^{\prime} 54^{\prime \prime} \mathrm{N}, 14^{\circ} 13^{\prime} 45^{\prime \prime} \mathrm{E}\right)$. Key plots have been established in valleys of Grendasselva, Aldegonda rivers and sea terrace in surroundings of Barentsburg aerodrome (Fig. 1).

The climate of Gronfjord coast is largely affected by oceanic influences of the subpolar zone. Precipitation rates are relatively low $-300-600 \mathrm{~mm} /$ year. Mean annual air temperature in the area (Barentsburg meteorological station) is $-6.18^{\circ} \mathrm{C}$ (Norwegian Meteorological Institute 2012; Fig. 2). Mean annual precipitation is $525 \mathrm{~mm}$ (mainly falls by snow). Recent studies revealed the increase in temperature of the active layer in Svalbard (Isaksen et al. 2007, Przybylak et al. 2010, Rachlewicz et Szczuciński 2008, Romanovsky et al. 2012). According to the data obtained in Petuniabukta the thaw depth is usually at about

\section{Study sites}

Grendasselva river valley is covered mainly by lichen-moss vegetation. It is characterized also by numerous patterned ground elements combined with lichenmoss and moss-lichens patches with rare inclusions of higher plants (mostly Lusula pilosa). Lusula pilosa habitats are connected with well-drained boggy sites within inshore zone. Soil cover is represented by Typic Cryosols on elevated sites and Histic Gleysols and Histosols on well-drained boggy sites (Fig. 2a).

Aldegonda river valley characterizes predominance of initial-formation types of soils on moraine material (mostly Leptic Cryosols) (Fig. 2b). Vegetation is presented
0.5-0.6 $\mathrm{m}$ (in June), and at the end of the summer season it reaches up to $1.2 \mathrm{~m}$ (Rachlewicz et Szczuciński 2008).

The bedrock of the studied area is formed mainly by crystalline rocks - metamorphic (phyllite and gneiss) with subordinate carbonates. The strata are mostly horizontal and tectonically undisturbed, but there are some smaller faults (Birkenmajer 1990).

Vegetation cover of the study area is formed by arctic tundra which consists of several different plant communities, where mosses are dominants (Koroleva et al. 2008). It should be noticed that vegetation is represented mainly by discontinuous tundra patches).

Soil diagnostics was carried out according to "Classification and Diagnostics for Russian soils" (Shishov et al. 2004) and "World reference base for soil resources" [2]. Additionally descriptions of plant communities according to dominant approach have been performed for each key plot.

by sporadic plant communities comprised by Lusula pilosa and thin lichen-moss layer (developed only in well-moistened micro depression).

The site established on the marine terrace in surroundings of Barentsburg aerodrome is covered by relatively rich tundra, which is represented by different plant communities (Lusula pilosa, Sphagnum species are dominants). On the top of the terrace compressed barren circles are quite abundant. Soil catena has been established within this key plot. Soil types are represented by Typic Cryosols in upper parts of catena, Gleysols and Histic Gleysols in lower parts (Fig. 2c). 


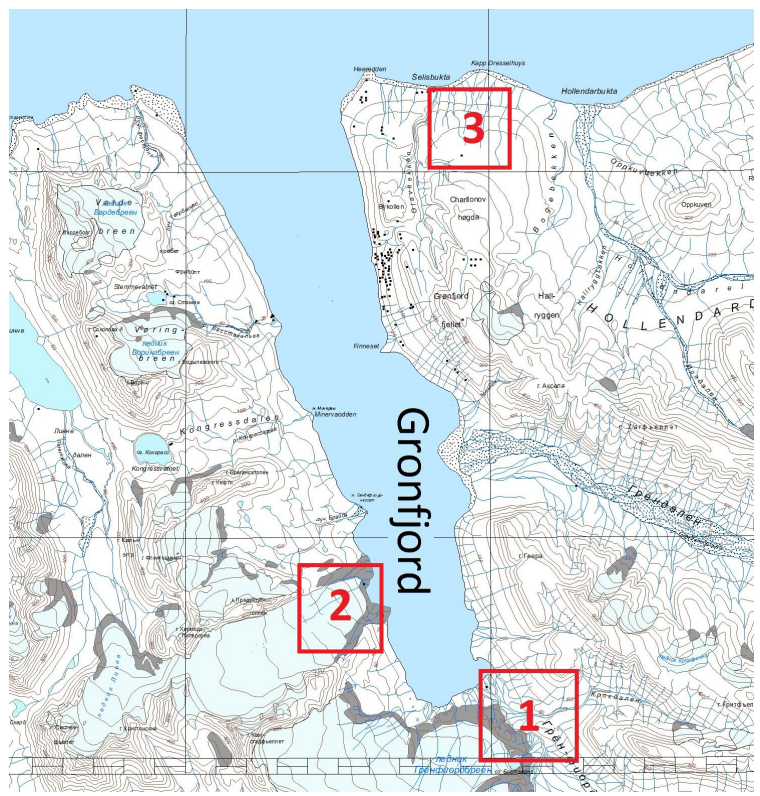

Fig. 1. The map of study area (key plots). 1 - Grondasselva river; 2 - Aldegonda river; 3 - sea terrace in surroundings of Barentsburg aerodrome.

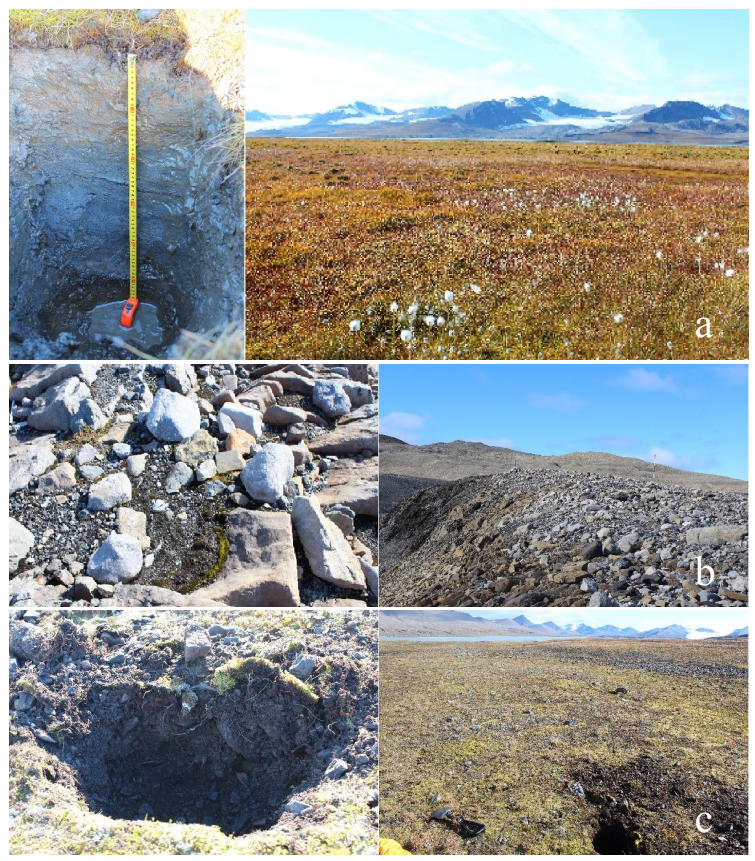

Fig. 2. Morphological and taxonomic diversity of soils of Gronfjord sea terraces: a - Histic gleysol (with buried humus horizon); $\mathrm{b}$ - Initial soil-forming processes on moraine material; $\mathrm{c}$ - Cryosol (with histic material). 
Data on texture classes and coarse fraction contents are presented in Table 1. Soils of Grondasselva river key plot are characterized by predominance of loam texture class in upper horizons and silty clay in lower ones. Coarse fraction content varies from $18.4 \%$ to $30.2 \%$ and decreases slightly from the topsoil to the lower horizons. Soil

\section{Geophysical methods and measurements}

During the field work investigation of electrical resistivity of soil and permafrost layers has been performed. Measurements of electrical resistivity of soil and permafrost layers were performed with portable device Landmapper ERM-02 (Landviser, LLC). The device can measure electrical resistivity in a surface soil layer of the depth from $2 \mathrm{~cm}$ down to $20 \mathrm{~m}$, which is set by varying the size of a four-electrodes probe.

The distance between the A and B electrodes ranged from $10 \mathrm{~cm}$ to $3 \mathrm{~m}$ while the distance between the $\mathrm{M}$ and $\mathrm{N}$ electrodes was constant $-10 \mathrm{~cm}$. For processing and visualization purposes a 1D layer model (ZondIP software) have been used.ZondIP1d program is aimed to one-dimensional re- of Aldegonda river key plot is characterized by sand (unsorted) texture class. Coarse fraction content is significantly higher-up to $75.2 \%$. Soils of surroundings of Barentsburg aerodrome are characterized mainly by silty clay texture class and lower contents of coarse fraction. sistivity and induced polarization vertical electrosounding data interpretation. Basis for this software is the conception of multistation interpretation. Profile line data is considered as a reflection of geological section. It means that multi-station data of profile line is whole, and not set of separated curves. This model provides the data on apparent electrical resistivity values changes with the depth $(\rho)$, the layers thickness (h) and layer depth (z). In total, 7 soil profiles from the different key plots of Gronfjord sea terraces have been investigated. Field data on electrical resistivity are presented by 3 values from each measured point. The geometric factor $\mathrm{K}$ was first calculated for all the electrode spacings using the formula:

$$
K=\pi(A B / 2+M N / 2) *(A B / 2-M N / 2) /(2 * M N / 2)
$$

Eqn. 1

where $\mathrm{AB}$ - source electrodes spacing, $\mathrm{MN}$ - receiver electrodes spacing.

The values obtained were then multiplied with the resistance values to obtain the apparent resistivity, $\rho$, values. Then the apparent resistivity, $\rho \mathrm{a}$, values were plotted against the electrode spacing's $(1 / 2 \mathrm{AB})$ on a log-log scale to obtain the VERS sounding curves using an appropriate computer software ZondIP. The VERS data and their modeling have been used to de- rive the geoelectric sections for the various profiles. Three resistivity sounding curve types were obtained from the studied area. These are the $1(\rho 1>\rho 2<\rho 3), 2(\rho 1<\rho 2<\rho 3)$ and $3(\rho 1>\rho 2<\rho 3>\rho 4)$ type curves. Solid red line denotes the layer model and the thin lines show the calculated model apparent resistivity curve. 


\section{Results}

Results on electrical resistivity values (Ra) within the soil profiles are presented in the Table 1. The general trend of the profile change of soil resistivity values is increasing with the depth. This data corresponds with data obtained previously for permafrost affected soils of another polar region - Antarctic (Abakumov et Parnikoza 2015).

Data on VERS measurements provides significant information about heterogeneity of electrical resistivity values within the soil profile. Typically values of apparent electrical resistivity increase rapidly on the active layer - permafrost border at the depths of 100-120 cm (from hundreds Ohm*m to thousands Ohm*m). The trend of increasing Ra values within the permafrost strata can be explained by morphological reason (increasing of homogeneity in permafrost layer to the depth). The number and size of cracks in permafrost are getting less to the depth. That is the reason for lower amounts of water, iron oxides, dissolved organic matter accumulated in lower parts of permafrost layer compared to the gleic-permafrost geochemical border (Abakumov et Tomashunas 2016).

\begin{tabular}{|c|c|c|c|}
\hline Soil horizon, depth & Texture class & Coarse fraction content, $\%$ & Temperature, ${ }^{\circ} \mathbf{C}$ \\
\hline \multicolumn{4}{|c|}{ Grondasselva river } \\
\hline \multicolumn{4}{|c|}{ Typic Cryosol } \\
\hline $0-1 \mathrm{~cm}$ & Loam & 30.2 & 4.2 \\
\hline $1-28 \mathrm{~cm}$ & Loam & 27.2 & 2.6 \\
\hline $28-33 \mathrm{~cm}$ & Silty clay & 19.2 & 1.8 \\
\hline \multicolumn{4}{|c|}{ Histic Gleysol with buried humus horizon } \\
\hline $0-2 \mathrm{~cm}$ & - & - & 5.4 \\
\hline $2-20 \mathrm{~cm}$ & Loam & 28.3 & 3.7 \\
\hline $20-51 \mathrm{~cm}$ & Loam & 24.4 & 2 \\
\hline $\begin{array}{c}51-53 \mathrm{~cm} \text { (buried } \\
\text { humus horizon) }\end{array}$ & Loam & 20.7 & 0.8 \\
\hline $53-57 \mathrm{~cm}$ & Silty clay & 18.4 & 0.4 \\
\hline \multicolumn{4}{|c|}{ Aldegonda river } \\
\hline \multicolumn{4}{|c|}{ Leptic Cryosol } \\
\hline $0-10 \mathrm{~cm}$ & Sand, unsorted & 75.2 & 3.7 \\
\hline $10-15 \mathrm{~cm}$ & Sand, unsorted & 65.3 & 3.2 \\
\hline \multicolumn{4}{|c|}{ Sea terrace in surroundings of Barentsburg aerodrome } \\
\hline \multicolumn{4}{|c|}{ Typic Cryosol } \\
\hline $0-4 \mathrm{~cm}$ & Loam & 25.2 & 5.8 \\
\hline $4-22 \mathrm{~cm}$ & Silty clay & 18.4 & 4.5 \\
\hline $22-29 \mathrm{~cm}$ & Silty clay & 16.7 & 3.7 \\
\hline \multicolumn{4}{|c|}{ Histic Gleysol } \\
\hline $0-2 \mathrm{~cm}$ & - & - & 5.4 \\
\hline $2-25 \mathrm{~cm}$ & Silty clay & 19.4 & 4.2 \\
\hline $25-50 \mathrm{~cm}$ & Silty clay & 18.3 & 3.4 \\
\hline
\end{tabular}

Table 1. Texture class, coarse fraction contents and temperature of studied soils. 
Data obtained using ZondIP softaware let to determine characteristic features of electrical resistivity vertical profiles for soil-permafrost layers of studied key plots. Active layer thickness has been also determined using ZondIP software.

Soils of Grondasselva river key plot are characterized by two types of profile distribution of Ra values (Table 2, Fig. 3). However, both of them are featured by gradual character of increasing $\mathrm{Ra}$ values to the depth. The first type is observing in the soil of over-drained site (boggy landscape) starting with relatively low electrical resis- tivity values in the topsoil. The second type is starting with significantly higher values of Ra and connected with less-drained site. The difference is caused by different amount of gravitational type of water in the topsoil. It has been previously shown that electrical resistivity is decreasing with higher amount of gravitational type of water in soil pores (Samouëlian et al. 2005, Pozdnyakov 2008, Magnin et al. 2015). The depths of the active layer-permafrost boundary lies on the depth $80-90 \mathrm{~cm}$ and are shown in Fig. 3.

\begin{tabular}{|c|c|c|c|}
\hline $\begin{array}{c}\text { VERS } \\
\text { section name }\end{array}$ & $\begin{array}{l}\text { P-modelled } \\
\text { resistivity, } \\
(\Omega \mathrm{m})\end{array}$ & $\begin{array}{l}\text { Z-bottom layer } \\
\text { depth, } \\
\text { (m) }\end{array}$ & $\begin{array}{c}\text { Depth of the layer with } \\
\text { fixed value of electrical } \\
\text { resistivity, } \\
\text { table (m) }\end{array}$ \\
\hline \multirow{3}{*}{ Grondasselva river } & 2.9 & 0.1 & 0 \\
\hline & 429818.5 & 0.4 & 0.1 \\
\hline & 87085.7 & & 0.5 \\
\hline \multirow{3}{*}{ Grondasselva river } & 27.7 & 0.04 & 0 \\
\hline & 8.6 & 0.09 & 0.04 \\
\hline & 730.8 & & 0.1 \\
\hline \multirow{4}{*}{ Grondasselva river } & 1.4 & 0.08 & 0 \\
\hline & 474 & 0.1 & 0.08 \\
\hline & 124.4 & 0.4 & 0.2 \\
\hline & 21033.6 & & 0.6 \\
\hline \multirow{4}{*}{ Aldegonda river } & 1.4 & 0.09 & 0 \\
\hline & 39389.9 & 0.4 & 0.09 \\
\hline & 926 & 0.5 & 0.5 \\
\hline & 613.6 & & 1 \\
\hline \multirow{2}{*}{$\begin{array}{c}\text { Sea terrace in } \\
\text { surroundings of } \\
\text { Barentsburg aerodrome }\end{array}$} & 12.1 & 0.09 & 0 \\
\hline & 4170.6 & & 0.09 \\
\hline \multirow{2}{*}{$\begin{array}{c}\text { Sea terrace in } \\
\text { surroundings of } \\
\text { Barentsburg aerodrome }\end{array}$} & 5.9 & 0.2 & 0 \\
\hline & 35173.6 & & 0.2 \\
\hline \multirow{2}{*}{$\begin{array}{c}\text { Sea terrace in } \\
\text { surroundings of } \\
\text { Barentsburg aerodrome }\end{array}$} & 9.9 & 0.2 & 0 \\
\hline & 85824.2 & & 0.2 \\
\hline
\end{tabular}

Table 2. Electrical resistivity in soils and permafrost of Gronfjord sea terraces. 

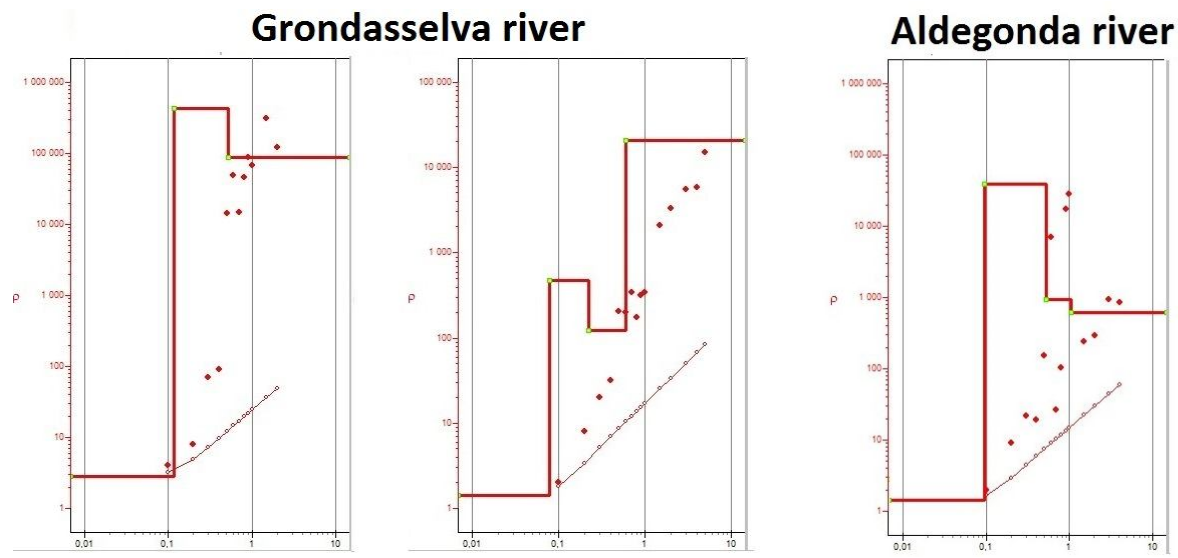

\section{Surroundings of Barentsburg aerodrome}
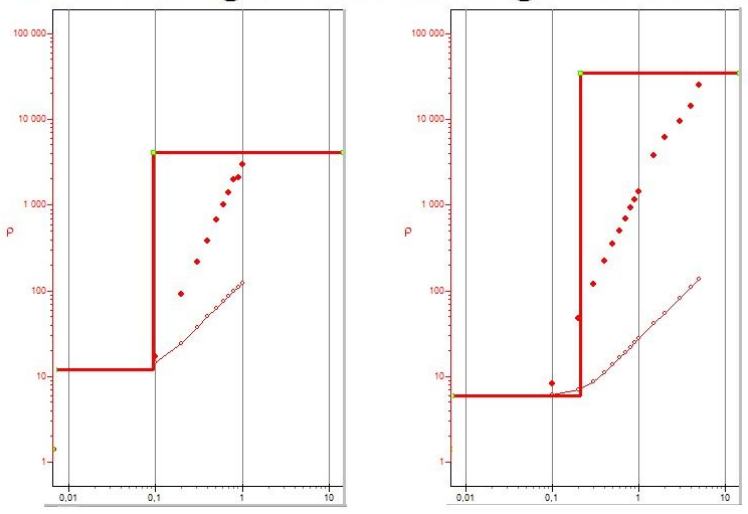

Fig. 3. Resistivity curves and models for studied sites. Solid line (1) denotes the layer model, dot line (2) denotes measured values and thin line (3) denotes calculated model curve. Vertical scale ER values, $\mathrm{Ohm} * \mathrm{~m}$, Horizontal scale $-\mathrm{AB} / 2$ distance, $\mathrm{m}$.

Soils of Aldegonda river key plot shows low values of electrical resistivity in the upper part of profile (Table 2, Fig. 3). Then Ra values are significantly fluctuating due to cryogenic mass exchange process in the weak-sorted material of initial soil. After passing the fluctuating depth $(80-90 \mathrm{~cm})$ $\mathrm{Ra}$ values increase with a depth revealing active layer-permafrost boundary. Then vertical profile of electrical resistivity values is featured by monotonous increasing trend.

Electrical resistivity values profile distribution in soils of catena (sea terrace in sur- roundings of Barentsburg aerodrome) is featured by monotonous increasing of $\mathrm{Ra}$ values to the depth (Table 2, Fig. 3). However, topsoil in upper parts of catena and lower parts are different in context of electrical resistivity. The first ones are characterized by lower values due to higher amount of clay material in upper horizons. The correlation between clay content and electrical resistivity values has been discussed earlier (Pozdnyakov 2008, [1] - Manual 2007). 
The active layer-permafrost boundary lies at the depth 140-150 cm. Higher values of this indicator compare to another key plots caused by higher influence of

\section{Discussion}

Studying of soil-permafrost layer by vertical electrical resistivity sounding method lets to determine significant information on homogeneity/heterogeneity of this layer and inter alia features of geochemical barriers (Abakumov et Parnikoza 2015, Samouëlian et al. 2005). Besides, active layer thickness and soil-permafrost boundary are one of the most important indicators for polar soils classification. Moreover, data obtained could be used for detailed soil cover mapping (Pozdnyakov 2008).

The data obtained are coincided fairly well with soil morphological properties described during the field work. Relatively low values of electrical resistivity in upper horizons might be in some cases caused by high amount of water accumulated in po-

\section{Conclusions}

There are many factors affect soil electrical properties. Permafrost related processes, water content, texture class are the most sufficient for studied soils. Performed study let to determine the degree of heterogeneity of soil-permafrost layers.

Permafrost provides complications to profile distribution of electrical resistivity values within the soil strata. In its turn permafrost strata are featured by relatively simple Ra values profile distribution. Several trends in profile distribution of electrical resistivity values of soils and permafrost of marine terraces of Gronjord have been revealed. The major is related to monotonous increasing of electrical resistivity values with a depth. In some cases values of apparent electrical resistivity increase rapidly aerodrome functioning (located closely to the key plot) and presence of former research polygon for permafrost studies (there are many remains of boring machinery.

rous media. In other cases sharp increasing of electrical resistivity values within the soil profile might be caused by specific properties of bedrock (subordinate carbonates). Also it should be noticed that geochemical barriers on the border of active layer and permafrost have been distinguished by soil morphology as well as by vertical electrical sounding.

It should be also noticed that for some soil types significant differences in interpretation in sense of classification state compared to the previous works conducted in the area of study (Pereverzev et Litvinova 2010) were determined. This confirms the thesis about the non-stable state of polar soils classification and taxonomy.

on the border of active layer-permafrost layer. The main trend for permafrost strata is connected with monotonous increasing of $\mathrm{Ra}$ values to the depth and may be explained by increasing of Ra within the soil depth in relation with increasing of permafrost density.

The depths of active layer-permafrost boundary have been distinguished using ZondIP software and further interpretation. It has been revealed that regional differences in this indicator may be explained not only by local differences in thermal regime of soil and permafrost layers, but also by different character of anthropogenic influence on key plots. Vertical profiles of electrical resistivity of each key plot have prominent and characteristic features de- 
scribed different nature of the main forces affect soil and permafrost electrical properties.

Well-drained and boggy sites are characterized by predominance of water content and water quality factors in creation of electrical resistivity vertical profile (especially in soil layers). For less-drained sites texture class factor is becoming more forceful.
It should be conclude that used $1 \mathrm{~d}$ model serves as a good basis for interpretation of data on electrical resistivity and let to distinguish characteristic features describing behavior of electrical properties within the soil-permafrost layer and especially to establish geochemical barriers on the active layer-permafrost border.

\section{References}

Abakumov, E. V., Parnikoza, I. Yu. (2015): Determination of the soil-permafrost border in selected plots of Antarctic Peninsula on the base of vertical electric sounding data. Ukrainian Antarctic Journal, 14: 138-142.

Abakumov, E. V., Tomashunas, V. M. (2016): Electric resistivity of soils and upper permafrost layer of the Gydan peninsula. Polarforschung, 86: 27-34, doi:10.2312/polarforschung.86.1.27.

BirkenMajerk, K. (1990): Hornsund, Spitsbergen, Geology, 1: 75 000, map with explanations. University of Silesia, Katowice, 21 p.

Dobrovolsky, V. V. (1990): Geochemistry of soils of Spitsbergen. Pochvovedenie, 2: 5-20 (in Russian).

Forman, S. L., Miller, G. H. (1984): Time dependent morphologies and pedogenic processes in raised beaches, Broggerhaalvoya, Spitsbergen, Svalbard archipelago. Arctic and Alpine Research, 16: 381-394.

Goryachkin, S. V. (2010): Soil Cover of the North (Patterns, Genesis, Ecology, Evolution) Publishing house GEOS, 414 p. (in Russian).

Hoekstra, P., McNeill, D. (1973): Electromagnetic probing of permafrost. In: The North American Contribution to the Second International Conference on Permafrost. National Research Council, National Academy of Sciences, 517 p.

Hoekstra, P., Sellmann, P. and Delaney, A. (1975): Ground and airborne resistivity surveys of permafrost near Fairbanks, Alaska. Geophysics, 40: 641-656.

IsAKsen, K., BenestaD, R. E., HARris, C. and Sollid, J. L. (2007): Recent extreme near surface permafrost temperatures on Svalbard in relation to future climate scenarios. Geophysical Research Letters, 34, doi: 10.1029/2007GL031002.

Koroleva, N. E., Konstantinova, N. A., Belkina, O. A., Davydov, D. A., Lihachev, A.Yu., Savchenko, A. N. and Urbanavichene, I. N. (2008): Flora and vegetation of Gronfjord coast (Spitsbergen archipelago). Apatity, K\&M, 132 p. (in Russian).

Magnin, F., Krautblatter, M., Deline, P., Ravanel, L., Malet, E. and Bevington, A. (2015): Determination of warm, sensitive permafrost areas in near-vertical rockwalls and evaluation of distributed models by electrical resistivity tomography. Journal of Geophysical Research, doi: 10.1002/2014JF003351.

Mann, D. H., Sletten, R. S. and Ugolini, F.C. (1986): Soil development at Kongsfjord, Spitsbergen. Polar Research, 4(1), 1-16.

OlHOEFT, G. R. (1978): Electrical properties of permafrost: Proc. $3^{\text {rd }}$ International conference on Permafrost. Edmonton, Alberta. National Research Council of Canada, Ottawa, Canada, 1: 127132.

Pereverzev, V. N., Litvinova, T. I. (2010): Soils of sea terraces and bedrock slopes of fiords in Western Spitsbergen. Eurasian Soil Science, 43(3): 239-247.

Plichta, W., KuczynskA, I. (1991): Metal contents in soils of Kaffiyyra, Spitsbergen. Polish Polar Research, 12(2): 183-193. 
Pozdnyakov, A. I., Pozdnyakova, L. A. and Karpachevskit, L. O. (2006): Relationship between Water Tension and Electrical Resistivity in Soils. Eurasian Soil Science, 39, Suppl. 1, 78-83.

PozDNYAKov, A. I. (2008): Electrical soil parameters and soil formation process. Pochvovedenie, 10: 1188-1197 (in Russian).

Przybylak, R., Arazny, A. and KejnA, M. (2010): Differentiation and long-term changes in ground temperature in the vicinity of the Nicolaus Copernicus Polar Station (NW Spitsbergen) in the summer season from 1975 to 2009. Problems of Polar Climatology, 20: 103-120.

RACHLEWICZ, G., SzCZUCINSKI, W. (2008): Changes in thermal structure of permafrost active layer in a dry polar climate, Petuniabukta, Svalbard. Polish Polar Research, 29(3): 261-278.

Romanovsky, V. E., Smith, S. L., Christiansen, H. H., Shiklomanov, N. I., Streletskiy, D. A., Drozdov, D. S., Oberman, N. G., Kholodov, A. L. and Marchenko, S. S. (2012): Permafrost. Arctic Report Card: Update for 2012-Permafrost. NOAA Climate Program Office through the Arctic Research Program, Washington DC.

Samouëlian, A., Cousin, I., Tabbagh, A., Bruand, A. and Richard, G. (2005): Electrical resistivity survey in soil science: a review. Soil and Tillage Research, 83: 173-193.

ScotT, W. J., KAY, A. E. (1988): Earth resistivities of Canadian soils: Can. Elect. Assoc., Montreal. Vol 1, Main Rep., Vol 2., Site data.

Scott, W. J., Sellmann, P. V. and Hunter, J. A. (1990): 13. Geophysics in the Study of Permafrost. In: S. H. Ward (ed.): Geotechnical and Environmental Geophysics. Society of Exploration Geophysicists, Tulsa, 355-384.

Shishov, L. L. Tonkonogov, V. D., Lebedeva, I. I. and Gerasimova, M. I. (2004): Classification and diagnostics of Russian soils. Moscow: Dokuchaev Soil Science Institute. Oykumena, $342 \mathrm{p}$. (in Russian).

Tarnocai, C., Canadell, J., Schuur, E., Kuhry, P., Mazhitova, G. and Zimov, S. (2009): Soil organic carbon pools in the northern circumpolar permafrost region. Global Biogeochemical Cycles, 23: 1-11.

TomashunAs, V. M, ABAKumov, E. V. (2014): The content of heavy metals in soils of Yamal peninsula and Belyi Island. Gigienaisanitariya, 6: 26-31 (in Russian).

Zubrzycki, S., Kutzbach, L. and Pfeiffer, E.-M. (2014): Permafrost-affected soils and their carbon pools with a focus on the Russian Arctic. Solid Earth, 5: 595-609.

\section{Other sources}

[1] Manual on Vertical Electric Sounding. Marchenko M.N. (ed.), 2007, Moscow, Moscow State University, 30 p. (in Russian).

[2] World reference base for soil resources. FAO, 2014, $181 \mathrm{p}$. 